11-1-1991

\title{
Federalism and the Prevention of Groundwater Contamination
}

Denise D. Fort

University of New Mexico - School of Law

Follow this and additional works at: https://digitalrepository.unm.edu/law_facultyscholarship

Part of the Environmental Law Commons, and the Water Law Commons

\section{Recommended Citation}

Denise D. Fort, Federalism and the Prevention of Groundwater Contamination, 27 American Geophysical Union 2811 (1991).

Available at: https://digitalrepository.unm.edu/law_facultyscholarship/8

This Article is brought to you for free and open access by the UNM School of Law at UNM Digital Repository. It has been accepted for inclusion in Faculty Scholarship by an authorized administrator of UNM Digital Repository. For more information, please contact amywinter@unm.edu, Isloane@salud.unm.edu, sarahrk@unm.edu.

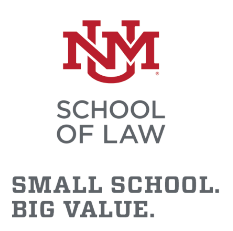

BIG VALUE. 


\title{
Federalism and the Prevention of Groundwater Contamination
}

\author{
DENISE D. FORT \\ Natural Resources Center, University of New Mexico School of Law, Albuquerque
}

\begin{abstract}
The federal government has increasingly come to predominate in environmental protection. The underlying policies behind that shift are still being debated in the context of groundwater protection. Many of the reasons that led to national statutory schemes for air, surface water, toxics and other environmental media are applicable to groundwater and a greater federal role in the protection of groundwater is appropriate.
\end{abstract}

\section{INTRODUCTION}

The last three decades have witnessed a revolution in America's concern about its environment. This concern has been manifested in the passage of laws, creation of agencies, and widespread changes in what had been routine industrial and municipal practices. In short order, major regulatory schemes have been directed at the protection of air and surface water quality, at landfills, at pesticides, and at hazardous waste, to name but some of the new programs.

Thirty years ago, the notion that the federal government would tell a city where to put its trash, how to construct a landfill site, what type of effluent could be discharged from its sewage facilities, and what its incinerators could emit into the air would have been regarded as ludicrous. Insofar as pollution was recognized as a problem, local governments had the responsibility for abating it, with state governments later assuming water pollution and then air pollution programs [Davies and Davies, 1975, pp. 152, 158].

The reallocation of responsibilities for environmental protection began with the passage of the Water Pollution Control Act of 1948 [U.S. Congress, 1948] and the Air Pollution Control Act of 1955 [U.S. Congress, 1955]. Both pieces of legislation did little more than provide financial assistance to the states, but they are notable for indicating the national interest in water and air pollution [Advisory Commission on Intergovernmental Relations (ACIR), 1981, p. 6].

The first Earth Day in 1970 is a convenient marker for the period in which environmental problems emerged as major political issues. Congress passed legislation that established federal programs for pollution control, with a state's ability to assume these programs conditioned on its establishing a federally set minimum level of pollution control. For example, the Clean Air Act Amendments of 1970 [U.S. Congress, 1970] required that states demonstrate plans for attainment of national air standards or face federal control of air pollution and loss of funds. Legislation in the areas of solid waste, noise pollution, pesticides, toxic chemicals, hazardous waste transportation, and other areas followed.

With Ronald Reagan's election as president in 1980, the presumption that federal programs were the answer to national problems was challenged. The Reagan administration proposed a comprehensive restructuring of relations between the federal and state governments, and an executive

Copyright 1991 by the American Geophysical Union. order was promulgated which expressed this philosophy [U.S. Executive Department, 1987]. For state programs, the essence of the "new federalism" was the decentralizing and defunding of federal environmental programs [Lester, 1990], which was accompanied by the administration's well-known antipathy to environmental programs [Lash, 1984]. In the current administration, budgetary issues have increased in importance when the Congress and executive branch weigh the creation of major new federal programs.

The current debate over whether groundwater quality should be protected by a comprehensive federal law provides an opportunity to consider the nature of the federalstate relationship in environmental protection. There is no national consensus over the proper role for each level of government. Further, the alignment of different groups varies in relation to factors such as the perceived strictness of the respective legislative and administrative entities. For example. although industries usually prefer state control, this preference can dissolve in instances when federal regulators are viewed as more congenial to industry. Environmental interests generally prefer federal control, but with the important caveat that more stringent state controls not be preempted. State bureaucracies generally prefer to retain their own control, and thus they are often aligned with industry in opposing federal control. Conversely, state governments may align with environmentalists where state control is threatened hy preemptive federal legislation. The application of this sort of calculus to the choice of regulatory forum has been dubbed "the politics of opportunism" [Fairfax, 1982].

This paper is an examination of some of the public policy considerations that enter into the assignment of a regulatory scheme to one level of government rather than another. Because groundwater protection is the current subject of congressional consideration and action by state and federal agencies, no attempt is made to exhaustively chronicle topical developments.

\section{Existing Federal and State Regulation}

Ground water contamination, which is now recognized as a major threat to a critical resource and to the nation's health, was not generally accorded such importance when Congress first formulated policies to protect air and surface water. Senator Durenberger, a proponent of national groundwater legislation, has commented, [Durenberger, 1986, p. 80]

We have only recently begun to appreciate the relationship between human activities on the land surface and the contam- 
ination of water supplies beneath it. In fact, by encouraging land disposal of society's wastes, the environmental statutes which have produced visible improvement in air and surface water quality have resulted in invisible degradation of ground water quality.

Reports issued in the 1980 s signalled a growing national awareness of the environmental concerns associated with groundwater. For example, reports of the U.S. Congress Office of Technology Assessment (OTA) [1984], and the Environmental Protection Agency (EPA) [1984] documented the extent of known groundwater contamination. These incidents of groundwater contamination were coupled with warnings of the country's growing reliance on groundwater (the General Accounting Office (GAO) [1988] reported that groundwater use increased from 34 billion gallons (129 billion $\mathrm{L}$ ) per day in 1950 to 89 billion gallons ( 337 billion $\mathrm{L}$ ) per day in 1980).

Indications of congressional awareness of groundwater pollution can be discerned in many pieces of environmental legislation. Section 208 of the Federal Water Pollution Act Amendments of 1972 [U.S. Congress, 1972] directed the states to devise state "plans" to protect groundwater. No real sanctions beyond loss of planning monies were attached to the failure to adopt control measures, and the provision has been widely viewed as a failure [see Novick et al., 1988, section 13.01(3)].

The EPA was given explicit authority to control underground injection wells for the disposal of pollutants in the Safe Drinking Water Act [U.S. Congress, 1974]. Following the conventional model, this statute established a minimum program, to which states were required to conform or risk loss of control of the program to the federal government.

The Safe Drinking Water Act also gives EPA the authority to promulgate numeric standards for drinking water. In recent amendments, Congress directed that states develop programs to protect groundwater at wells that provide public water systems [U.S. Congress, 1986].

Two of the most important pieces of environmental legislation adopted at a national level addressed the problems posed by hazardous waste. When Congress enacted the Resource Conservation and Recovery Act of 1976 [U.S. Congress, 1976], it explicitly moved to address the contamination of groundwater from hazardous waste.

The Comprehensive Environmental Response Compensation and Liability Act [U.S. Congress, 1982], provided for the clcanup of chemically contaminated waste sites. Cleanup under Superfund has not been cheap, and much of the appropriation has been directed to the remediation of sites with groundwater contamination.

In all, there are over 16 federal statutes authorizing some aspect of groundwater pollution control [OTA, 1984]. Despite the presence of groundwater protection measures in these statutes, there is no comprehensive federal scheme governing groundwater contamination and legislative proposals to create one have not to date met with success in Congress [Kenski, 1990; Getches, 1985; U.S. Congress, 1988a].

Environmental groups support federal legislation because of their belief that there are important sources of groundwater contamination that are unregulated or minimally regulated under federal law. Implicit in the resulting call for federal legislation, as will be discussed below, is the contention that state governments do not adequately regulate these sources. A coalition of environmental groups has identified the sources of groundwater contamination that it would see regulated federally: (1) municipal and industrial so-called "nonhazardous" waste landfills and impoundments, tanks, bulk storage, transfer facilities, and underground injection of wastes which are not regulated through permit programs under the Resource Conservation and Recovery Act subtitle $\mathrm{C}$ or the Safe Drinking Water Act; (2) agricultural and silvicultural activities, including application of pesticides and fertilizers to the land surface, intensive animal husbandry, and agriculture waste impoundments; (3) energy and mineral production related wastes; (4) subsurface disposal systems, including septic tanks and cesspools; and (5) transportation and utility-related sources involving salt, pesticides and oil and grease [Clean Water Action Project et al., 1988].

State regulation of groundwater pollution presents a mixed picture, not susceptible to easy characterization. Unlike other media, the quality of a state's groundwater is not easily ascertained. The Office of Technology Assessment [1984] noted the limited amount of ambient quality monitoring performed by states, and the difficulty of basing public policy on monitoring results has been noted. [Roberts and Butler, 1984]. As a result, a state with a number of sites of groundwater contamination may be incorrectly judged to have a greater problem than a state which has not spent a comparable amount of money searching out groundwater contamination. It is similarly incorrect to conclude that the latter state has more effective policies to prevent contamination.

Forty-one states have adopted some form of groundwater standards [GAO, 1988]. Comparison of state programs is made difficult because only 26 states utilize numeric standards and no two states have the same set of numeric standards [GAO, 1988]. Commentators have concluded that state programs are not comprehensive [National Research Council, 1986; Glicksman and Coggins, 1986] and a state by state description by Patrick et al. [1987] reveals states where little regulatory activity has occurred. An examination of state programs found that some states with groundwater legislation might have narrowly targeted regulations, such as programs addressing leaking underground storage tanks [Morandi, 1989]. In that instance, state regulations may merely represent state assumption of a program that would otherwise be federally administered.

On the other hand, state attention to groundwater quality can definitely be said to be increasing. After an expenditure of approximately $\$ 35$ million, EPA reports that all states and territories have prepared groundwater strategies [Reilly, 1991]. Evidence of vigorous and creative programs in certain states is abundant [Morandi, 1989].

Standards are often accompanied by an aquifer classification scheme. How a state decides which aquifers to protect, and to what degree they are protected, is difficult to compare to policies in another state, because of the varying characteristics of aquifers, and the judgment inherent in these determinations.

Finally, without detailed information as to how standards are interpreted and applied, even a comparison of numeric standards might not be especially enlightening in determining how effective state programs are on a state by state basis. One needs to know if important sources of contamination have been excluded or if existing contamination has been 
grandfathered in. The administration of a regulatory scheme can be as important as its existence, with de facto exceptions to enforcement hidden from a statutory reading.

\section{Should Federal Legislation Be Enacted?}

Arguments over pollution control rarely take the form of contentions that pollution is acceptable. Similarly, it would be difficult to argue that groundwater should not be protected, and predictably, that position is not part of the policy debate. The national policy debate is over whether regulatory controls should be mandated by the federal government or initiated and designed by individual states. In practical terms, the debate is over whether all states must meet some federally established minimum of regulation.

Importantly, in approaching this debate one ought not assume that federal regulation would address all sources of pollution, nor that it would incorporate standards stricter than those of every state. In contrast to those environmental programs which were initiated at the Congressional level, groundwater regulation is already in place in many states, and some states may have regulated more stringently than the Congress may choose to do.

The ineptness of the federal government in administering some of its environmental programs should also not be forgotten. The hazardous waste program, which should be an important component of a groundwater protection program, is the major example of this. Whether the program was stalled through a deliberate strategy or through mismanagement and incompetency [Lieber, 1983], is less relevant than the bungled results. The Reagan administration, with its active hostility to environmental regulation and the slowdown in environmental rule making it achieved, showed that federal administration and enforcement is not necessarily more vigorous than that of every state.

The other important observation to be made in approaching this debate is that it is over policy, not the constitutional powers of the federal government. State governments have historically regulated the use of groundwater [Smith, 1985], but the Supreme Court has identified a national interest in how state governments conduct that regulation. Thus, in Sporhase versus State of Nebraska [1982], the Court struck down a Nebraska statue that restricted interstate transfers of groundwater. The Court's holding rested on a finding that groundwater was an article in interstate commerce, and that Nebraska's particular restriction on its transfer offended the Constitutional protection offered interstate commerce. In dictum, the Court suggested how federal regulation might be constitutionally justified, "Ground water overdraft is a national problem and Congress has the power to deal with it on that scale" (p. 954).

Federal regulation of activities within a state that affect interstate commerce has been upheld based on the adverse impact of the activities on interstate commerce. Thus, federal regulation of the surface mining of coal was upheld based on the congressional finding that the adverse effects of coal mining burdened interstate commerce [Hodel versus Virginia Surface Mining and Reclamation Association, 1981]. Parallel findings that groundwater pollution causes health and economic damages would provide ample justification for federal regulation of activities that pollute groundwater $[\mathrm{Ng}, 1989]$.

\section{Questions to Ask in Examining Who Regulates}

Stewart [1977] has elucidated the arguments for centralization of environmental programs. He describes the critical issues as the practical challenge of regulating industries that may move their operations as a response to regulation, the efficiency of regulation, the relationship of industry to local units of groundwater, interstate pollution issues, and the political issues which are peculiar to environmental politics. Countering arguments for decentralization are the diseconomies of scale that arise from inappropriate national regulation, the impairment of self-determination, and the lack of an uniform agreement across the country that national policies represented in environmental legislation are fair or sensible. This taxonomy is helpful to the examination of how groundwater should be regulated.

\section{Interstate Flight and Industry Muscle}

Preeminent in the arguments for national legislation is the reluctance of states to impose environmental controls in advance of other states. The states have long feared that industries will flee as more stringent environmental regulations are enacted. The impetus for adoption of national air and surface water legislation came, in part, from the difficulties faced by jurisdictions which regulated industries more stringently than did other jurisdictions. Mayors of major cities supported a strong federal role because they desired to retain industry, and at the same time control pollution [ACIR, 1981, p. 49].

The potential that a jurisdiction will not impose regulations for fear of discouraging businesses is as applicable to mobile sources of groundwater pollution as it has been for pollution of other media. The costs of preventing or controlling groundwater pollution can be large, and the costs of remedying existing pollution are many orders of magnitude larger. Industries opposing groundwater controls invoke the familiar refrain that controls will kill the goose that lays the golden egg.

This argument can be used by an industry even where, strictly speaking, the operation is not itself mobile. For example, mining concerns have used it to oppose state taxes, threatening to concentrate their operations in low-tax states. There are some potential sources of groundwater pollution for which mobility has no apparent relevance, such as septic tanks for residential waste and small-scale farming sources.

A corollary to the fear of industry flight is the perception that state governments are unable, or unwilling, to regulate polluters effectively. The Congress's early efforts to control air and water pollution, deference to state interests dictated an incremental approach. This deference was a "prescription for inaction; few states voluntarily wrote or enforced pollution controls" [Rosenbaum, 1985, p. 36]. Federal action followed, based on the "feeling on the part of many federal policy-makers that the states had at least 20 years to act decisively and effectively with little or no result. . . " [ACIR, 1981, p. 54]. However, there have been instances when industrial support for federal air quality legislation came from a fear of stronger state laws [Elliot et al., 1985].

Another reason that state governments have not responded to the need for environmental regulation is readily identifiable in the ability of an industry to dominate the political structure of a particular state, while lacking corresponding national power [Rosenbaum, 1985, p. 164; Reh- 
binder and Stewart, 1985]. Governors may have little interest in enforcing environmental policies when their economic development plans are threatened [Manley, 1987, p. 667]. Indeed, passivity may be "quintessentially rational behavior" when regulating a state business [Bowman and Lester, 1985, p. 161]. The "favorable business climate" that most governors strive for is not perceived to be enhanced by stringent environmental controls [Bowman, 1985].

The underlying tenets of this argument have not changed since the adoption of the earlier national environmental schemes, although a more discerning understanding of the differences among states is now possible. Just as there is a sufficient history of federally administered environmental programs to mark varying attitudes by the federal executive, so too have scholars begun to compare the efforts of different states in environmental protection [Lester, 1986, 1990] and to compare the attitudes of federal and state regulators [Gormley, 1987].

The reduced funding of the "new federalism" has provided an opportunity for comparison among the states of reactions to federal cutbacks. The significant finding for purposes of the environmental federalism debate is that marked variations exist among the states [Davis and Lester, 1987]. Predictors of regulatory commitment have been devised [Davis and Lester, 1988; Rowland et al., 1988], and the respective capability and willingness of states to assume groundwater programs has been examined [Regens and Reams, 1988]. One commentator has categorized the states as "progressives," "strugglers," "delayers" and "regressives" [Lester, 1990], characterizations which aptly convey the rift separating the states.

The intervening decades have also made clear that selected industries command enormous power on a national level, with which they have been able to procure exemptions from federal pollution measures. For example, the mining industry, the source of many serious instances of groundwater pollution, enjoys favored treatment in several federal regulatory schemes. Indeed, there are instances when a state government might be more willing than Congress to exercise regulatory power over an industry. California has frequently moved earlier and more protectively than the national government against aspects of oil development, for example.

Despite these shifts in the orientation of the federal executive branch and a growing environmental activism in some state governments, the configuration of environmental, industrial, and state positions on the proper locus of groundwater regulation has not changed. The strong preference of environmentalists for national regulation and the industrial preference for state regulation remain intact.

The former governor of Arizona, Bruce Babbitt, relates that former Interior Secretary James Watt attempted to utilize the presumed hostility of state governors to national regulation. He informed the nation's governors of a proposed EPA policy on groundwater regulation, stating, "This is another example of high-handed, preemptive Federal intrusion. Please join me in resisting any Federal action on groundwater, and I look forward to your early response in defense of State sovereignty and States rights" [U.S. Congress, 1987a]. Contrary to its original intent, this appeal sparked interest in states to work together on groundwater protection, and led to the National Groundwater Policy Forum, a task force which endorsed a federal role in groundwater management [U.S. Congress, 1987a].
Generally, however, state governments, which opposed federal regulation in the $1960 \mathrm{~s}[A C I R, 1981$, pp. 11, 50], continue to oppose expanded federal regulation in this area. Two associations of water administrators have been outspoken in their opposition to national control of groundwater quality: the Western States Water Council and the Association of State and Interstate Water Pollution Control Administrators [U.S. Congress, $1987 b, 1988 b$ ]. The position of the latter organization is especially notable because its constituent agencies presumably have support of water quality as their primary mission.

Despite the difficulty of generalizing about the ability of states to regulate industries, the alignment of interest groups favoring and opposing federal legislation looks much the same as it did in earlier environmental battles. Industrial and business interests have generally opposed a national program. The Chemical Manufacturers Association, the American Mining Congress, and the Farm Bureau have testified in opposition to a centralized groundwater control program [U.S. Congress, 1988b]. Environmentalists have supported the enactment of a national groundwater control law [U.S. Congress, 1987b; Bureau of National Affairs, 1988].

\section{Efficiency of Regulation}

Another factor which favors national regulation is the high costs of generating certain types of regulations. The costs are incurred in the development and presentation of scientific evidence which is required in determining such issues as what constitutes injury to humans or harms the ecology of the natural world. Much of the standard setting done by environmental agencies relies on studies and testing, the duplication or analysis of which is expensive and nonproductive. For example, the amount of mercury which is harmful to humans does not vary from Vermont to California, although the two state governments might wish to make different judgments about the acceptability of risk, the costs of control, and the amount a citizen is likely to ingest from other sources.

National standards, most notably drinking water standards, are now relied upon by some states in establishing groundwater standards, thereby achieving some of the efficiencies of national regulation (although with standards not intended for this use). But, without a provision of state or federal law mandating their use, regulators must still defend their reliance on federal research in state proceedings.

Ultimately, national standards for groundwater quality are not sufficient by themselves to provide a controlling argument for central regulation, unless the federal government were also authorized to classify groundwater. Without some form of classification (or the designation of a single classification), standards alone are not sufficient for regulation. The power to classify waters is one which states will be extremely reluctant to cede to the federal government. And environmentalists, many of whom oppose any degradation of groundwater quality, regard standards with suspicion because they can be used to sanction, rather than prevent, pollution.

The efficiency of developing uniform engineering standards at a national level is also relevant. Technological controls are at the core of much environmental regulation. Pollution from underground tanks, for example, should be prevented through tank performance standards and installation requirements, not by the setting of ambient standards for the groundwater surrounding a tank. Design alternatives, costs of control, and 
management practices will not vary much across state lines, although states might apply different judgments regarding appropriate costs than do federal regulators.

Whether regulatory efficiency is a dispositive factor in an argument for centralized controls on groundwater, then, depends in part on the sort of controls that are envisioned as part of a federal law. Technology-based controls, which have pollution prevention, rather than mitigation, as their goal, are increasingly supported by the environmental community. EPA engages in this sort of national protection scheme when it refuses registration of a pesticide.

The argument for efficiency carries with it a threat to environmental interests. Insofar as pollution controls are based on technological controls, and the manufacture and distribution of goods through national systems is involved, the compelling arguments for national controls will be accompanied by demands for preemption of conflicting or more stringent state or local controls. This issue is addressed below.

\section{Interstate Movement of Pollutants}

Congressional action dealing with air and surface water pollution has also been based on the interstate movement of pollutants. The observation that pollution does not respect jurisdictional boundaries and the threat of conflicts among states over interstate pollution lent great weight to the need for federal legislation [see Novick et al., 1988, section 6.02(2); American Bar Association ( $A B A), 1982$, p. 5].

Groundwater also moves across state boundaries, although the extent of interstate groundwater pollution is presumably far less than it is for air and surface water. Dycus [1984] argues that the interstate nature of some groundwater pollution necessitates a federal response. Our common border with Mexico and the importance of the shared groundwater resource might be even more compelling. Mexico is affected by the groundwater programs, or lack thereof, of four states which are heavy consumers and users of groundwater [Teclaff, 1982; Utton, 1982].

As important as the physical movement of pollutants is, the interstate economic consequences of pollution might be more persuasive as an argument for national legislation. Because cleanup of contaminated groundwater can involve the expenditure of a substantial commitment of federal tax dollars, the relevant spillovers are economic as much as physical, and federal taxpayers have a strong interest in preventing pollution in other states.

\section{Insulated Federal Regulators}

Stewart [1977, p. 1217] has cited one other factor which proceeds from his view that environmental regulation involves the "sacrifice of preference-satisfaction in order to fulfill duties to others." His contention is that federal bureaucracies" "very size, professional orientation, and remoteness also makes them comparatively less sensitive to public discontent when the economic and social costs of such programs become apparent. . . " [Stewart, 1977, p. 1218].

In states where only minimal support exists for environmental regulation, a federal regulator will be more likely to attempt to enforce groundwater regulations against a powerful industry than would a state regulator. Federal regulators are sometimes despised because of their very imperviousness to local pressures, and on occasion appear to have successfully implemented national programs despite local opposition. This factor would clearly fuel environmentalists' preference for a federal program, since strong enforcement is valued.

\section{Unfair Regulation Resulting From a National Approach}

Stewart also identifies the rationales antithetical to those which militate for centralization of environmental regulation. Just as economies of scale may result from national regulation, diseconomies of scale may result where uniform regulation results in unfairness. The imposition of the same requirements for scrubbers on a power plant burning lowsulfur coal as on a facility burning high-sulfur coal illustrates this point. Requiring costly controls on cleaner coal seems unfair from a state perspective, even if national social and economic goals are achieved through the regulation.

The great differences in the geohydrography of the nation have frequently been cited as a reason that national regulation of groundwater is inappropriate. Both the likelihood and the consequences of pollution may vary with local conditions, as may the availability of alternative sources and the uses to which groundwater is put.

The weight afforded these arguments depends on what sort of regulation is sought for the sources that are currently unregulated under federal law. To the degree that a federal program were based on manufacturing and technological mandates, or national discharge standards, the consideration given to local conditions would be slight and inefficiencies, as used in this argument, could result. National classification schemes for groundwater might also result in inefficiencies, if groundwater for which there is no current nor future use were stringently protected. The inefficiency argument has been offered against many federal pollution programs. The countervailing considerations presumably lie in other possible national goals, such as preventing economic competition over rights to pollute, and furthering national policies of pollution prevention, regardless of known economic efficiencies. If states were allowed to classify groundwater, then some of the efficiency concerns would be addressed.

\section{Loss of Self-Determination}

There is little question that state boundaries mark important political differences regarding the environment. Stewart cites the impairment of self-determination which occurs from centralization of environmental regulation: "Federal dictation of environmental policies depreciates the opportunity for and value of participation in local decisions on such matters" [Stewart, 1977, p. 1220]. While this is commonly presented as a conflict between a local preference for economic growth and the federal preference for environmental quality, local values which support strongly protective regulation are also, albeit less frequently, overrun by national regulatory policies. In choosing a national program, the value given by decision makers to local control is starkly weighed against the importance of achieving national goals.

\section{Is Groundwater Unlike Other Environmental Media?}

As national environmental regulation has become the norm for many types of pollution, an effort has been made to distinguish groundwater from other environmental media. To the degree that groundwater is best protected through land use 
controls, the assertion is made that land use is an area for local regulation, not state or federal control. From this it is argued that federal regulation of groundwater is inappropriate [U.S. Congress, 1987a, pp. 159-163; Buresh, 1986, p. 1433].

Land use controls of some sort are the most promising means of control for nonprofit source pollution, such as runoff from agricultural and urban development. While the belief that land use is uniquely the province of local governments is not legally compelled [Buresh, 1986], there are powerful practical and institutional reasons to believe that comprehensive land use planning will not occur on a federal level. Nonetheless, groundwater controls could be imposed outside of land use planning, as federal statutes governing the siting of hazardous waste disposal sites demonstrate. For example, disposal of hazardous wastes in landfills may be prohibited, or a disposer forced to demonstrate that wastes will not migrate from the site. Also, land use planning does not adequately address pollution caused by existing operations, where control strategies will be needed for existing problems. Finally, even where land use controls are used for the prevention of pollution, some standard must be used for reference in determining acceptable levels of pollution. Planning does not obviate the need for setting these environmental standards, nor does it determine whether the state or federal government should set them. The connection between land use and groundwater contamination is indeed real, but land use controls will not address all of the sources of groundwater pollution, nor answer all of the questions involved in those sources which are regulated [see Roberts and Butler, 1984].

Water regulators from the western states have also objected to federal regulation of groundwater pollution because they are concerned that control of pollution will deprive state governments of control over water quantity. Control over water allocations has historically been a matter of state power, vigilantly guarded against federal interference [U.S. Congress, 1987b, p. 115].

Quantity and quality of water are indeed interrelated [Getches, 1985], and the states' fears of losing their control over water allocation is a critical issue in this debate, perhaps the one where feelings run deepest. How well grounded those fears are is a different matter. More work must be done to isolate legitimate state concerns in this area, and to determine whether proposed groundwater quality controls are truly incompatible with these concerns. The magnitude of the national interest in groundwater quality may eventually result in an effect upon state allocation policies; there are few areas of the natural environment which are now solely matters of state control.

\section{Should State Regulations be Preempted?}

In any instance where federal legislation is found to be necessary to address an environmental problem, the question can be raised whether the federal legislation should be exclusive or whether it should permit state action which exceeds the federal legislation. Preemption, simply stated, can arise when a state statute conflicts with a federal statute, or when federal regulation is so pervasive that it gives rise to the implication that Congress intended preemption [Rice versus Santa Fe Elevator Corporation, 1947, p. 230]. Preemption can also occur when Congress explicitly prohibits state legislation [Aloha Airlines, Inc. versus Director of Taxation, 1983, p. 12].

If national groundwater legislation is enacted because of the desirability of uniform regulation and because technologies are to be mandated, then industrial interests are likely to seek preemption of state regulations. This specter of preemption tries the depths of an environmentalist's commitment to the centralization of environmental programs. Conversely, it provides the incentive for industrial tolerance of national regulation [Elliot et al. 1985]. Having discovered a national interest in the abatement of a particular type of pollution and reasons for a national program, the Congress must still consider whether validity should be given to state preferences for yet more stringent environmental protection.

If the motive for national legislation is prevention of groundwater contamination, then permitting stricter state legislation would further that goal. To the degree that the desirability of uniform technology is a rationale for the assertion of national interests, then these two conflicting goals will need to be resolved by the Congress.

Preemption has been the exception in environmental lawmaking $\mid A B A, 1982$, p. 10|. The possibility of its application can provide industry with an incentive for federal regulation $[A B A, 1982$, p. 11] and force environmental interests to question seriously whether federal regulation is worth losing the benefit of more stringent state regulations.

\section{Conclusion}

Given the importance and immediacy of the environmental questions facing the nation, the pertinent consideration in the issue of who should regulate groundwater is how to effectively protect an important resource and the public health. This question has become more difficult to answer, rather than less so, after some 20 years of experience with environmental programs.

This analysis has shown that many of the factors that led to a greater federal role in environmental protection are applicable to groundwater, although in varying degrees among states. Because states are not monolithic in their attitudes toward environmental programs, the existence of more recalcitrant states points to some federal role, at least to prod and assist those states in moving to protect groundwater.

That said, the nature of the sources currently unregulated by federal statutes requires a more precise discussion of what a federal law should address. In some instances, national regulations will be more efficient than local regulation in bringing about groundwater protection, as when a pesticide is denied registration by the FPA. For some sources, such as septic tanks, a stronger role will need to be played by state and local governments.

The debate over federal groundwater legislation has been useful in challenging the familiar model of federal-state environmental relationships. Ideal federal legislation would acknowledge that state governments may be as likely as the Congress and the national regulatory agencies to reduce groundwater pollution. Development of new models of federal legislation that exhibit some humility toward state efforts has been attempted, and the groundwater issue is one where new models would be useful. Finally, for a federal program to be meaningful, the federal government should pay the true costs; it should not need to be said that a poorly funded program with substantial mandates to state governments will be unlikely to elicit a great deal of state support, although just this approach has been imposed by Congress in some environmental programs. 


\section{REFERENCES}

Advisory Commission on Intergovernmental Relations (ACIR), Protecting the environment: Politics. pollution, and federal policy, report, $59 \mathrm{pp}$., Washington, D. C., 1981.

Aloha Airlines, Inc. versus Director of Taxation, 464 U.S. 7, 1983.

American Bar Association ( $A B \Lambda$ ), The new federalism in environmental law: Taking stock, report, Washington, D. C., 1982.

Bowman, A., Hazardous waste managment: An emerging policy area within an emerging federalism, Publius, 15, 131-145, 1985.

Bowman, A., and J. Lester, Hazardous waste management: State government activity or passivity, State Local Gov. R., 17, 155$161,1985$.

Bureau of National Affairs, Environ. Rep., 19, 303, 420, 1988.

Buresh, J. C., State and federal land use regulation: An application to groundwater and nonpoint source pollution control, Yale Law J., $95,1433-1458,1986$.

Clean Water Action Project, Protecting the nation's groundwatcr: A proposal for federal legislation, report, $113 \mathrm{pp}$., Washington, D. C. 1988.

Davies, J. C., and B. Davies, The Politics of Pollution, 152 pp., Bobbs-Merrill, Indianapolis, Ind., 1975.

Davis, C.. and J. Lester, Decentralizing federal environmental policy: A research note, West. Polit. Q., 40, 555-565, 1987.

Davis, C., and J. Lester, Hazardous waste politics and the policy process, in Dimensions of Hazardous Waste Policy, edited by C. Davis and J. Lester, pp. 1-34, Greenwood, Westport, Conn., 1988

Durenberger, D., Groundwater policy: A need for federal participation, Forum Appl. Res. Publ. Policy, 79-86, 1986.

Dycus, J. S., Development of a national groundwater protection policy, Boston Coll. Environ. Aff. Law Rev., 11, 211-271, 1984.

Elliot, E., B. Ackerman, and J. Millian, Toward a theory of statutory evolution: The federalization of environmental law, $J$. Law Econ. Organ., l, 313-340, 1985.

Environmental Protection Agency (EPA), Groundwater protection strategy, report, 56 pp., Washington, D. C., 1984.

Fairfax, S., Old recipes for new federalism, Environ. Law, 12, $945-980,1982$

General Accounting Office (GAO), Groundwater quality: State activities to guard against contaminants, Rep. GAO/PEMD-88-5, 166 pp., Washington, D. C., Feb., 1988.

Getches, D. H., Controlling groundwater use and quality, Nat. Resour. Lawyer, 17, 623-645, 1985.

Glicksman, R., and G. Coggins, Groundwater pollution, II, An immodest proposal for a strategy to prevent groundwater pollution, Kans. Law R., 35, 75-193, 1986.

Gormley, W., Jr., Intergovernmental conflict on environmental policy: The attitudinal connection, West. Polit. Q., 40, 555-565, 1987.

Hodel versus Virginia Surface Mining and Reclamation Association, 452 U.S. 264, 1981.

Jorgensen, E. P. (Ed.), The Poisoned Well: New Strategies for Groundwater Protection, 384 pp., Sierra Club Legal Defense Fund, Island, Washington, D. C., 1989.

Kenski, H., Saving the Hidden Treasure: The Evolution of Ground Water Policy, 159 pp., Iowa State University Press. Ames, 1990.

Lash, J., A Season of Spoils, 385 pp., Pantheon, New York, 1984.

Lester, J., New federalism and environmental policy, Publius, I6, $149-165,1986$.

Lester, J., A new federalism? Environmental policy in the states, in Environmental Policy in the 1990s, edited by N. Vig and M. Kraft, pp. 59-79, CQ Press, Washington, D. C., 1990.

Lieber, H., Federalism and hazardous waste policy, in The Politics of Hazardous Waste Management, edited by J. Lester and A. Bowman, pp. 60-72, Duke University Press, Durham, N. C., 1983.

Manley, R. E., Federalism and the management of the environment, Urban Lawyer. 19, 661-681, 1987.

Morandi, L., State Groundwater Protection Policies: A Legislator's Guide, National Conference of State Legislators, Washington, D. C., 1989.

National Research Council, Groundwater Quality Protection, State and Local Strategies, 309 pp., National Academy Press, Washington, D. C.., 1986.

$\mathrm{Ng}$, L., A. drastic approach to controlling groundwater pollution, Yale Law J., 98, 773-791, 1989.

Novick, S. M. D. Stever, and M. Mellon (Eds.) Law of Environmental Protection, 2 vols., Clark Boardman, New York, 1988.
Patrick, R., E. Ford, and J. Quarles, Groundwater Contamination in the United States, 2nd ed., 513 pp.. University of Pennsylvania Press, Philadelphia, 1987.

Regens. J., and M. Reams, State strategies for regulating groundwater quality, Social Sci. Q., 69, 53-68, 1988.

Rehbinder, S. E., and R. Stewart, Environmental Protection Policy, $350 \mathrm{pp}$., Walter de Gruyter, Berlin, 1985

Reilly, W., Statement of William K. Reilly, administrator, U.S. Environmental Protection Agency, before the Committee on Agriculture, Nutrition and Forestry, United States Senate, Jan. 25,1991 .

Rice versus Santa Fe Elevator Corporation, 331 U.S. 218, 1947.

Roberts, R. S., and L. Butler, Information for state groundwater quality policymaking, Nat. Resour. J., 24, 1015-1041, 1984.

Rosenbaum, W. A., Environmental Politics and Policy, $328 \mathrm{pp}$., CQ Press, Washington, D. C., 1985.

Rowland, C. K., S. Lee, and D. Goetze, Longitudinal and catastrophic models of state hazardous waste regulation, in Dimensions of Hazardous Waste Politics and Policy, edited by C. Davis and J. Lester, pp. 93-116, Greenwood, Westport, Conn., 1988.

Smith, Z., Federal intervention in the management of groundwater resources: Past efforts and future prospects, Publiws, 15, 145-159, 1985.

Sporhase versus State of Nebraska, 458 U.S. 941, 1982.

Stewart, R. B., Pyramids of sacrifice? Problems of federalism in mandating state implementation of national environmental policy, Yale Law J., 86, 1196-1272, 1977.

Teclaff, L.. Principles for transboundary groundwater pollution control, Nat. Resour. J., 22, 1065-1079, 1982.

U.S. Congress, Water Pollution Control Act of 1948, Public Law: 845, 62 Stat. 758, 1948.

U.S. Congress, Air Pollution Control Act of 1955, Public Law 15y, 69 Stat. $360,1955$.

U.S. Congress, Clean Air Act Amendments of 1970, Public Law 9/-604, 84 Stat. 1713, 1970.

U.S. Congress. Federal Water Pollution Control Act Amendments of 1972, Public Law 92-500, 86 Stat. 816, 1972.

U.S. Congress, Safe Drinking Water Act, Public Law 93-523, 88 Stat. 1660.1974.

U.S. Congress, Resource Conservation and Recovery Act of 1976, Public Law 94-980, 90 Stat. 2759, 1976.

U.S. Congress, Comprehensive Environmental Response Compensation and Liability Act, U.S. Code, vol. 42, sect. 9601-9675. 1982. (Supplement, 1988).

U.S. Congress, Safe Drinking Water Act Amendments of 1986. Public Law 99-339, 100 Stat. 642, 1986.

U.S. Congress, To assess progress toward the development of a national groundwater protection program, hearing before a Subcommittee of the House Committee on Government Operations, 99th Congress, 1st Session, 1987 a.

U.S. Congress, Groundwater-Related Programs of the USGS and the EPA, hearings before the Senate Committee on Energy and Natural Resources, Subcommittee on Water and Power, 100th Congress, Ist Session, $1987 b$.

U.S. Congress, To protect the groundwater resources of the United States, $S$. 209I, 100th Congress, 2nd Session. Feb. 25, $1988 a$.

U.S. Congress, Protecting our nation's groundwater: The need for better program coordination, hearings before the Senate Committee on Governmental Affairs, Subcommittee on Governmental Efficiency, Federalism, and the District of Columbia, 100th Congress, 2nd Session, $1988 b$.

U.S. Congress Office of Technology Assessment (OTA), Protecting the Nation's Groundwater from Contamination, 503 pp.. U.S. Government Printing Office, Washington. D. C.. 1984.

U.S. Executive Department, Executive Order 12612, Fed. Regis., $52,41,685,1987$

Utton, A., Overview: Symposium on anticipating transhoundary resource needs and issues in the U.S.-Mexico border region to the year 2000, Nat. Resour. J., 22, 735-747, 1982.

D. D. Fort, Natural Resources Center, University of New Mexico School of Law, Albuquerque. NM 87131.

(Received March 14, 1989;

revised May 22, 1991;

accepted November 6,1990 .) 
